\title{
Human Factors on Motorcyclists’ Accidents Severity; Analysis Using Bayesian Network
}

\author{
Pada Lumba $^{\# 1}$, Imam Muthohar ${ }^{\# 2}$, Sigit Priyanto ${ }^{\# 3}$ \\ ${ }^{*}$ Civil and Environmental Engineering, Faculty of Engineering, Universitas Gadjah Mada \\ J1. Grafika no.2, Yogyakarta, 55281, Indonesia \\ pada.lumba@mail.ugm.ac.id \\ imam.muthohar@ugm.ac.id \\ spriyanto2007@yahoo.co.id
}

\begin{abstract}
This research focuses on the probability of accidents with severely and mildly injuries in motorcyclists. The probability of accidents took human factors only into consideration. $70.93 \%$ accidents that occured from July 1, 2015 until December 31, 2015 throughout Indonesia involved motorcycles. The research took place in Bekasi City, Indonesia. The samples comprised of 105 respondents who had experienced accidents, which were caused by human factors only. The results indicated that the probability of severely injuries accidents was $20 \%$, while mildly injuries amounted to $80 \%$. The accuracy calculation model employed new data from 24 respondents. The accuracy calculation model indicated that the Mean Absolute Deviation (MAD) was $\mathbf{2 1 . 2 9 \%}$. The model scenarios indicated that female drivers were more prone to severely injuries than men. The age group of 20 years and above had a greater probability to suffer severely injuries compared to the age group of 20 years and below. Reckless drivers were $30 \%$ more likely to suffer from severely injuries. Drivers who drove at $<50 \mathrm{~km} / \mathrm{h}$ and at speed $50-70$ $\mathrm{km} / \mathrm{h}$ were $20 \%$ more likely to experience accidents with severely injuries, and at $>70 \mathrm{~km} / \mathrm{h}$ it reaches $23 \%$.
\end{abstract}

Keywords: Accident, Bayesian, Mildly, Probability, Severely

\section{INTRODUCTION}

In $2009,57,726$ accidents occurred on highways, meaning that every 9.1 minutes an accident occurred in Indonesia. From the number mentioned, 28,000 people died at the crash site. This means that every 20 minutes there is one life lost on the highway (Indonesian National Police, 2009). In the following periods of 2010, 2011, 2012 the number of accidents increased by $15.18 \%$ to 66,488 cases, $63.48 \%$ to 108,696 cases, $8.51 \%$ to 117,949 cases respectively ([1], [2], [3]). However, in 2013 the number of accidents fell by $15.1 \%$ to just 100,106 accidents [4]. Road users around the age of 15-25 are the most prone group to traffic accidents in Indonesia. This age group experienced the most traffic accidents compared to other age groups, with 462 crash victims in fatal accidents, 531 victims in accidents with severely injuries, 2,797 victims in accidents with mildly injuries [13].

Accidents that occurred in the last two quarters (July 1, 2015 until December 31, 2015) throughout Indonesia were more likely to involve motorcycles than other vehicles, amounting to $70.93 \%$ or 30,628 accidents [13]. There are several factors that could cause accidents, which is : human error, roads and environment, and the performance of the vehicle. From these three factors, $75 \%$ of accidents are caused by human error factors, one of which was due to fatigue experienced by the drivers.

Spesific thing of this study with the samples comprised of respondents who had experienced accidents, which were caused by human factors only. Meaning that the probability severity accident was determine by ability or behaviour of the motorcyclists. In addition, there were not the study related to safe limit for highway driving for the mototcyclists until now unless for driver of the car. Based on the aforementioned various conditions, research is needed relating to reducing the risk of accidents, particularly for motorcyclists. This research aims to reduce the risk of accidents resulting in severely injuries to motorcyclists by identifying factors that affect the probability of accidents and the severity of severely and mildly injuries caused by human factors only.

\section{LITERATURE REVIEW}

Fatigue can reduce the ability of the driver to drive safely [7]. Some of the factors that influence the driver's fatigue and behavior on the road include: driver's occupation, trip duration, work routines, driving in the middle of the night, use of stimulants, work schedules and speed [11]. Driver's fatigue can be due to several factors such as lack of rest, long trip, and monotonous roads [15].

Motorcyclists' behavior, chaotic traffic and errors in a road's design contribute the most to the occurrence of motorcycle accidents [17]. Human error was a contributor factor of fatal motor vehicle crashes [10]. Motorcyclists who speed and drive recklessly cause accidents which could result in death (fatal), especially for young drivers, almost $20 \%$ of accidents which result in death (fatal) are due to drivers under the influence of 
alcohol, $4 \%$ of accidents are due the influence of drugs [5]. In addition, driver's behavior is also influenced by several factors that can increase the risk of accidents, including: age, gender, driver's experience, road conditions and characteristics of the vehicle [19]. The contributing factors for wrong-way crashes are alcohol impairment, darkness, and driver's age and skill [24].

The 1185 cases that led to death in accidents (fatal) in the United Kingdom (UK) from 1994-2005 indicated that drivers aged 20 and below are 12 times more likely to die in a (fatal) accident, and this condition decreases dramatically as the driver's age increases, then rose again after the driver passes the age of 65 [5]. A risk study of urban traffic accidents in Zagreb, Croatia, from 1999 to 2000, with a sample size of 528 people, indicated that men have a risk of death 2.69 times higher than women, and men who do not use seat-belts are more at risk of a fatal accident [22]. Young adults and students tend to violate traffic regulations more frequently. There are three main personality traits of young motorcycle riders, namely sensation seeking, amiability and impatience [23]. Men are less likely to ignore traffic regulations than women [20]. Male showed higher levels of difficulty associated with stopping, stopped waiting to turn, and slowing down situations. Meanwhile, females showed higher levels of difficulty related to identifying speeds and distance of oncoming traffic than males driver [6].

Bayesian Network (BN) is derived from Bayes' theorem, an approach to an uncertainty. Bayesian Network (BN) is a Directed Acyclic Graph (DAG) and is equipped with Conditional Probability Distribution Table (CPT) for each node. Each node represents a variable domain and each arrow between nodes represents a probabilistic dependency [18]. Bayes' theorem is used to calculate the probability of the occurrence of an event by the influence gained from the observation. This theorem describes the relationship between the probability of the occurrence of event A and the previous occurrence of event B.

Some examples of pictures and Bayesian calculation are shown in Figure 1 and 2.

Probability of accident severity in Figure 1 (a) can be calculated :

$\mathrm{P}(\mathrm{AS})=\mathrm{P}(\mathrm{AS} \mid \leq 20$ years $) \mathrm{P}(\leq 20$ years $)+\mathrm{P}(\mathrm{AS} \mid>20$ years $) \mathrm{P}(>20$ years $)$.

Probability of Accident severity in Figure 1 (b) can be calculated :

$\mathrm{P}(\mathrm{AS})=\mathrm{P}(\mathrm{AS} \mid \mathrm{Age} \leq 20$ years, Female $) \mathrm{P}($ Age $\leq 20$ years $) \mathrm{P}($ Female $)+\mathrm{P}(\mathrm{AS} \mid$ Age $\leq 20$ years, Male $) \mathrm{P}($ Age $\leq 20$

Years $) \mathrm{P}($ Male $)+\mathrm{P}(\mathrm{AS} \mid$ Age $>20$ years, Female $) \mathrm{P}($ Age $>20$ years $) \mathrm{P}($ Female $)+\mathrm{P}(\mathrm{AS} \mid$ Age $>20$ years, Male $)$

$\mathrm{P}($ Age $>20$ years) $\mathrm{P}($ Male $)$.

Where : $\mathrm{P}=$ Probability, $\mathrm{AS}=$ Accident Severity.

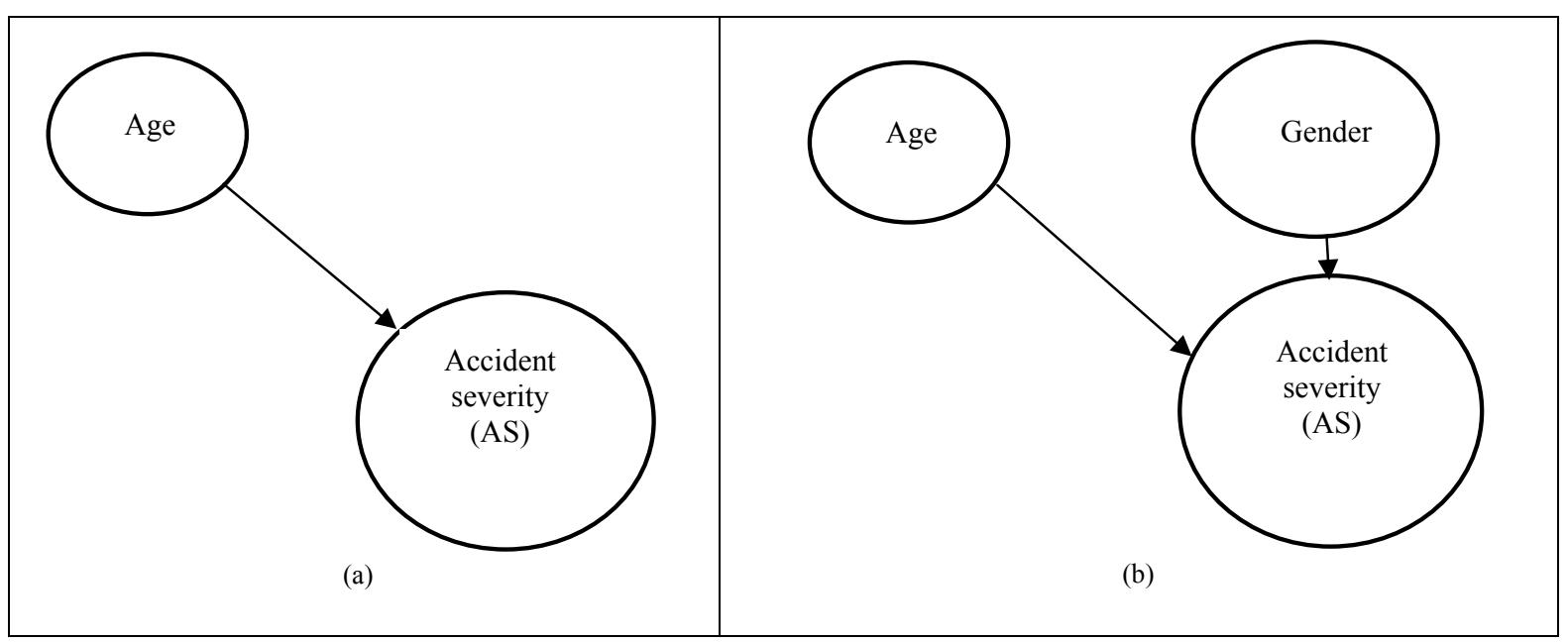

Fig. 1. Example of Bayesian Network

\section{METHOD, RESULTAND DISCUSSION}

The research took place in Bekasi City, Indonesia. Bekasi City borders on the north by Bekasi Regency, on the south by Bogor Regency and Depok City, and on the west by DKI Jakarta Province. Bekasi City has an area of approximately $210.49 \mathrm{~km} 2$ and is a satellite city of Jakarta. Traffic congestion frequently occurs during rush hour on the road connecting East Jakarta and Bekasi. The city is crossed by the JakartaCikampek toll road and Jakarta Outer Ring Road. Bekasi was chosen as the location for the study because it has the largest commuter line in Jabodetabek, around 2.43 million compared to other cities in Jabodetabek. Approximately $58.19 \%$ of commuter trips in Jabodetabek use the mode of motorcycles. In addition, $94.6 \%$ of commuter trips in the city of Bekasi have a travel time of over 30 minutes. Therefore, the city is appropriate to look for respondents for this study. Meanwhile, in order to validate the model, data were also collected outside Bekasi City.

Criteria for the respondents are motorcyclists who had experienced a traffic accident with a minimum 
age of 17 years old. The severity of the accidents comprised of severely to mildly injuries which the motorcyclists had experienced. Some attributes calculated in this study were: age, gender, long duration of driving before the accident, speed, fatigue, reckless behaviour. The data were collected by conducting measurable interviews where each respondent took approximately 30 minutes.

The data were collected from April to June 2016. Of the 246 respondents that experience accident in Bekasi City, Indonesia indicated that 105 respondent accidents were caused by human factor, 79 respondent accidents were caused by human, road and environment factors, 25 respondents accidents were caused by human and vehicle factors, 17 respondents accidents were caused by human, road and environment, vehicle factors, 15 respondents accidents were caused by road and enviroment factor, 3 respondent accidents were caused by road and environment, vehicle factors, 2 respondent accidents were caused by vehicle factors.

This study focus on the probability of accident took human factors only into consideration. The samples of this study consisted of 105 respondents who had experienced an accident due human factors only. The data then, were analyzed using the Bayesian Network method, which indicates a causal relationship between the variables contained in the structure of Bayesian Network and this Bayesian Network was built with the conditional probability approach. The Bayesian Network analysis in this study employed Software GeNIe 2.0. Variables and statistics based on data can be seen in Table I.

Table I

Variables and statistics

\begin{tabular}{|c|c|c|c|}
\hline No & Variables & Value & Percentage \\
\hline \multirow[t]{2}{*}{1} & \multirow[t]{2}{*}{ Accident severity } & Severely injury & 17.14 \\
\hline & & Mildly injury & 82.86 \\
\hline \multirow[t]{2}{*}{2} & \multirow[t]{2}{*}{ Gender } & Male & 80.00 \\
\hline & & Female & 20.00 \\
\hline \multirow[t]{2}{*}{3} & \multirow[t]{2}{*}{ Age } & $\leq 20$ years old & 67.62 \\
\hline & & $>20$ years old & 32.38 \\
\hline \multirow[t]{3}{*}{4} & \multirow[t]{3}{*}{ Speed } & $<50 \mathrm{~km} / \mathrm{h}$ & 59.05 \\
\hline & & $50-70 \mathrm{~km} / \mathrm{h}$ & 31.43 \\
\hline & & $>70 \mathrm{~km} / \mathrm{h}$ & 9.52 \\
\hline \multirow[t]{2}{*}{5} & \multirow[t]{2}{*}{ Reckless Behaviour } & Yes & 7.62 \\
\hline & & No & 92.38 \\
\hline \multirow[t]{2}{*}{6} & \multirow[t]{2}{*}{ Fatigue before to accident } & Yes & 34.29 \\
\hline & & No & 65.71 \\
\hline
\end{tabular}

The Structure of Bayesian Network of this study can be seen in Figure 2. Several attributes that affected the probability of accidents and severity of severely injuries and mildly injuries including : long duration of driving, gender, age, speed, fatigue, and reckless behavior while driving. The results of the Structure of Bayesian Network analysis indicated that the probability of an accident resulting in severely injuries was $20 \%$, while mildly injuries was $80 \%$. The accuracy rate of Bayesian Network Model was measured by calculating the Mean Absolute Deviation (MAD). In order to calculate the value of MAD, new data were used consisting of 24 respondents who had experienced an accident due to human factors only. Respondents were obtained from outside Bekasi City. The result of the model accuracy calculation indicated that the value of MAD was $21.29 \%$, meaning that an average absolute model deviation was $21.29 \%$, as shown in Table II.

Analysis of Bayesian Network indicated that 90 minute trip duration was the safe limit for higway driving, and after 90 minutes level of fatigue decreased as shown in Figure 3. Based on data, after a 90 minute trip the motorcyclists took a rest for some times because of fatigue. A previous research for driver of car indicated that a 80 minute trip was the safe limit for monotonous highway driving [21].

Model scenarios suggest that women were more prone to the risk of severely injuries than men, as shown in Figure 4 and 5 (scenarios 1 and 2). This research is in accordance with the studies conducted by [20] stating that men are less likely to ignore traffic regulations than women. In general, drivers will drive through small openings, speed, drive recklessly and overtake other vehicles on the wrong side of the road [20]. These conditions will certainly affect the probability of severely and mildly injuries from accidents. Based on data 
indicated that $66,67 \%$ of female driver violate traffic regulation before accident, meanwhile $33.33 \%$ of male driver violate traffic regulation before accident. This research is not in accordance with the studies conducted by ([16], [22]). Women are perceived less likely to fall into the high risk category because the risk of accidents increases with the number of trips [16]. Men have a 2.69 times higher risk of dying in traffic accidents on urban roads than women [22].

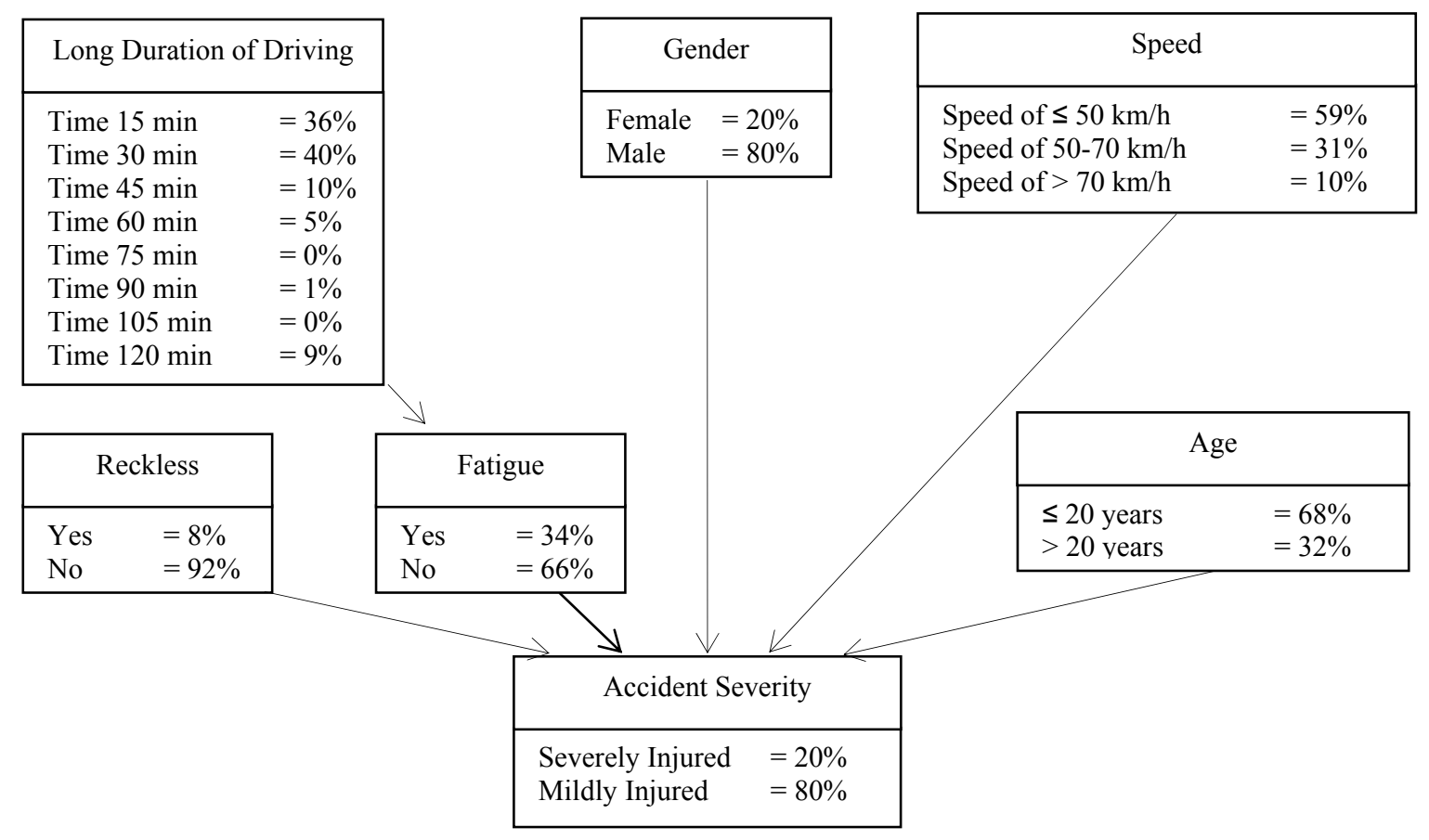

Fig. 2. Structure of Bayesian Network

Table II

The Calculation of the Mean Absolute Deviation (MAD) value

\begin{tabular}{|c|c|c|c|c|c|c|c|c|}
\hline \multirow{2}{*}{ Probability } & \multirow{2}{*}{ Fatigued } & \multirow{2}{*}{ Speed } & \multirow{2}{*}{ Reckless } & \multirow{2}{*}{ Age } & \multirow{2}{*}{ Gender } & \multicolumn{2}{|c|}{ Severely Injury } & \multirow{2}{*}{ Deviation \% } \\
\hline & & & & & & Actual \% & Model \% & \\
\hline 6 & Yes & $<50$ & No & $\leq 20$ & M & 0.00 & 17.00 & 17.00 \\
\hline 7 & Yes & $<50$ & No & $>20$ & $F$ & 0.00 & 50.00 & 50.00 \\
\hline 8 & Yes & $<50$ & No & $>20$ & M & 0.00 & 29.00 & 29.00 \\
\hline 14 & Yes & $50-70$ & No & $\leq 20$ & M & 0.00 & 20.00 & 20.00 \\
\hline 15 & Yes & $50-70$ & No & $>20$ & $\mathrm{~F}$ & 0.00 & 100.00 & 100.00 \\
\hline 16 & Yes & $50-70$ & No & $>20$ & M & 0.00 & 0.00 & 0.00 \\
\hline 20 & Yes & $>70$ & Yes & $>20$ & M & 0.00 & 0.00 & 0.00 \\
\hline 26 & No & $<50$ & Yes & $\leq 20$ & M & 0.00 & 0.00 & 0.00 \\
\hline 30 & No & $<50$ & No & $\leq 20$ & M & 0.00 & 12.00 & 12.00 \\
\hline 31 & No & $<50$ & No & $>20$ & $\mathrm{~F}$ & 25.00 & 50.00 & 25.00 \\
\hline 32 & No & $<50$ & No & $>20$ & M & 0.00 & 18.00 & 18.00 \\
\hline 38 & No & $50-70$ & No & $\leq 20$ & M & 0.00 & 15.00 & 15.00 \\
\hline 40 & No & $50-70$ & No & $>20$ & M & 0.00 & 12.00 & 12.00 \\
\hline \multirow[t]{2}{*}{46} & No & $>70$ & No & $\leq 20$ & M & 0.00 & 0.00 & 0.00 \\
\hline & \multicolumn{7}{|c|}{ Mean Absolute Deviation (MAD) } & 21.29 \\
\hline
\end{tabular}




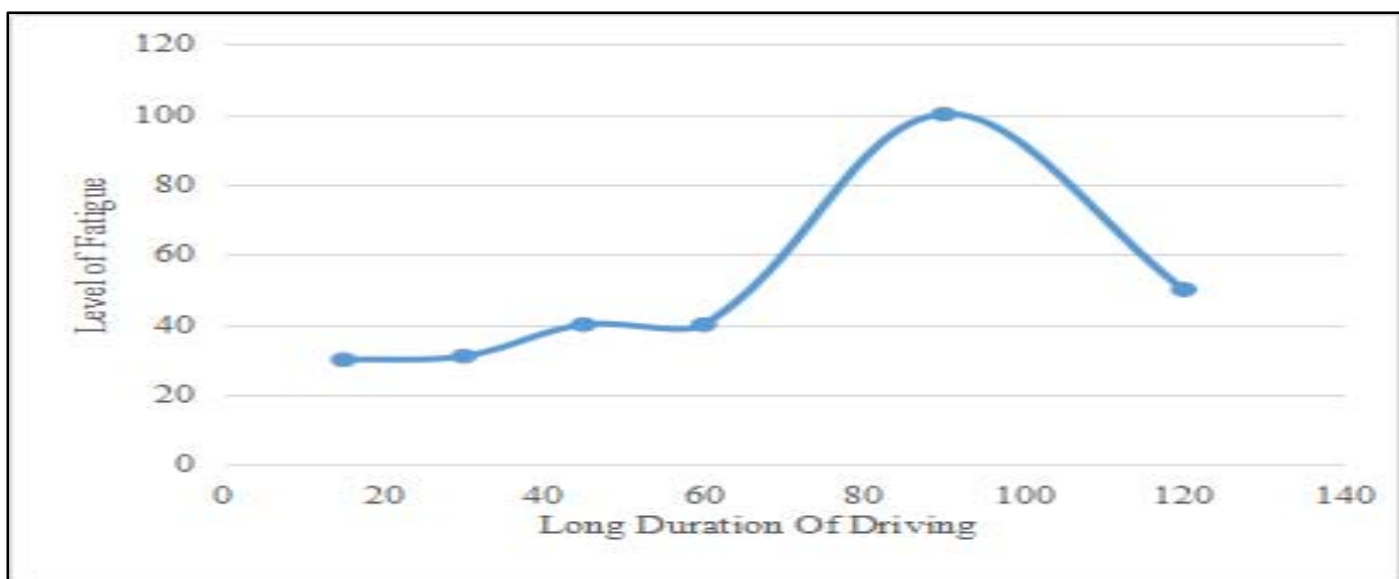

Fig. 3. Correlation between long duration of driving and level of fatigue

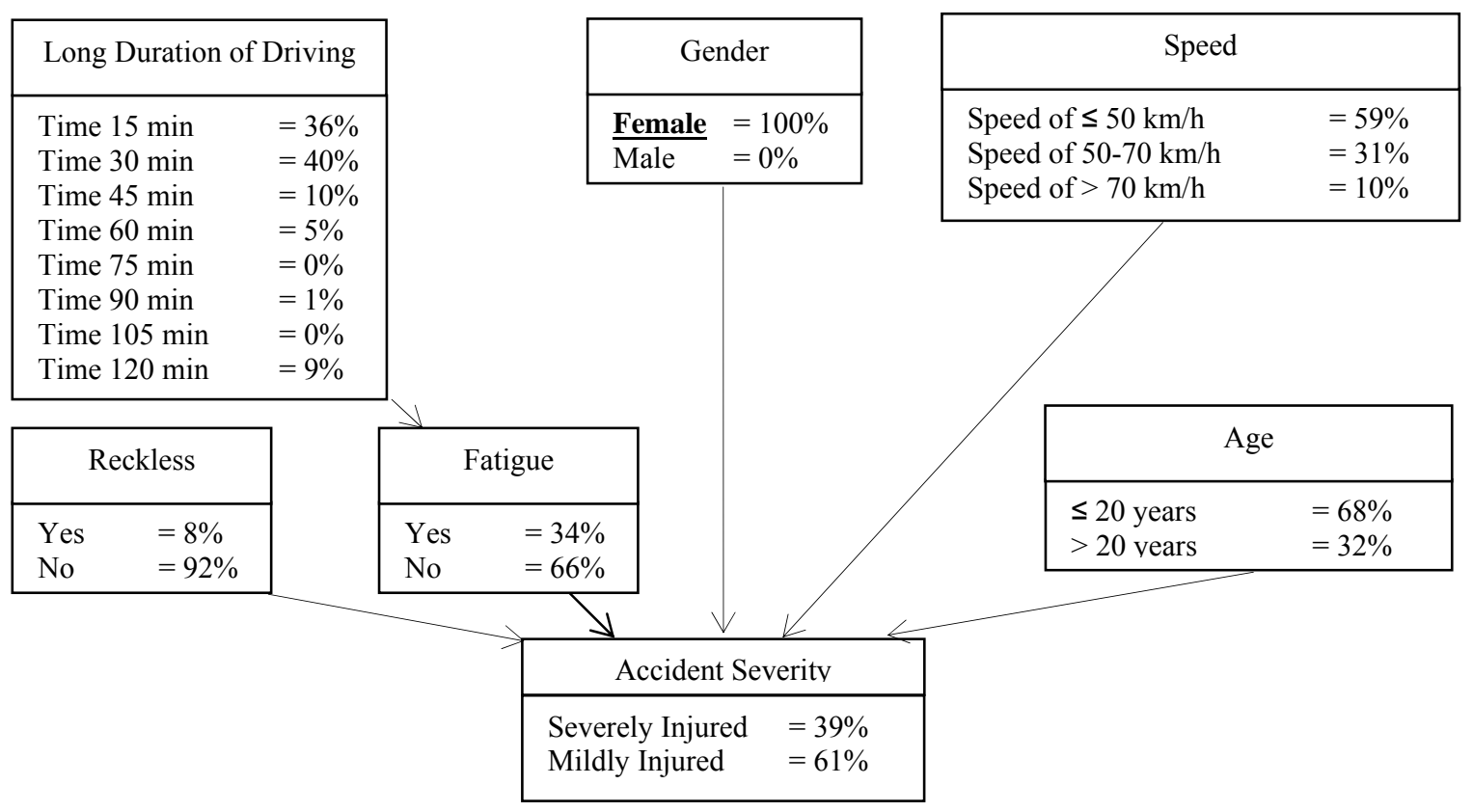

Fig. 4. Scenario 1

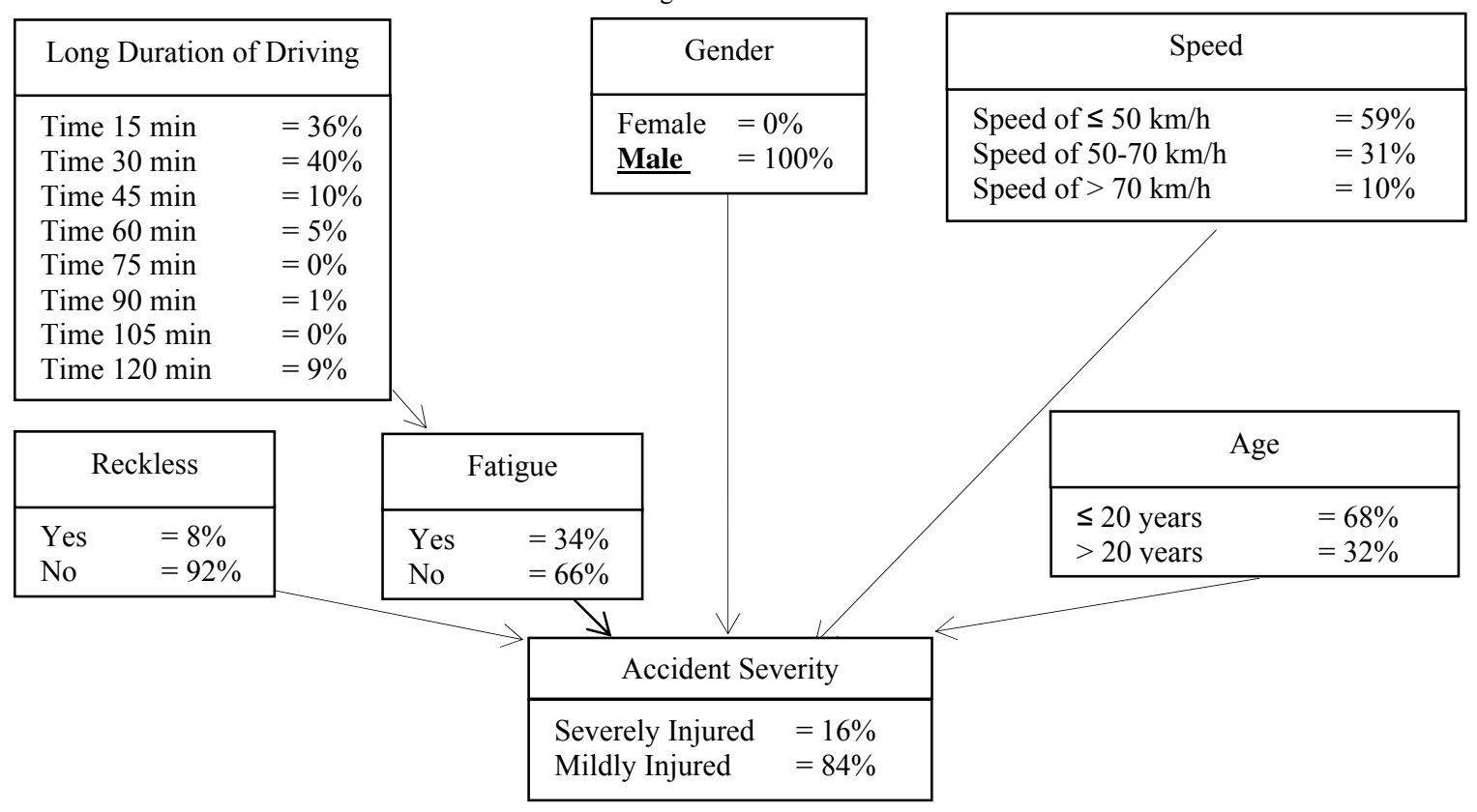

Fig. 5. Scenario 2 
Drivers aged 20 years and above are more likely to suffer severely injuries than those aged 20 years and below, as shown in Figures 6 and 7 (scenarios 3 and 4). This research is not in accordance with the studies conducted by ([22], [5], [8], [14]). Elderly people (65-year-old) have a significantly higher risk of suffering fatal accidents, or suffering severely rather than mildly injuries. The risk of accidents resulting in mildly injuries group is higher than the risk of fatal accidents or severely injuries group for the age under 30-years-old [22]. 25year-old drivers are less likely to perceive their risk of accident, and middle-aged drivers are likely to perceive their accidents between $30 \%-70 \%$. Drivers of 20 -year-old and under are almost 12 times more likely to suffer fatal accidents, and this condition decreases dramatically as the age of the driver increases, and then rises again after the drivers pass the age of 65 [5]. Drivers aged 60-64 and above are more likely to contribute to accident and in general it is a right-turn accident on intersection [5]. Young drivers have a maximum speed which is significantly higher than older drivers [8]. Wearing a helmet lowers the average probability of accidents for motorcyclists; and young motorcyclists on average are more likely to suffer from severely injuries or fatal accidents [14]. This research is not in accordance with the previous studies because the samples comprised of 105 respondents who had experienced accidents, which were caused by human factors only. Meaning that the probability severity accident was determined by ability or behaviour of the driver. Based on data indicated that $35,29 \%$ drivers aged 20 years and above had experienced fatigue before excident, and 33,8\% drivers aged 20 years and below had experienced fatigue before accident.

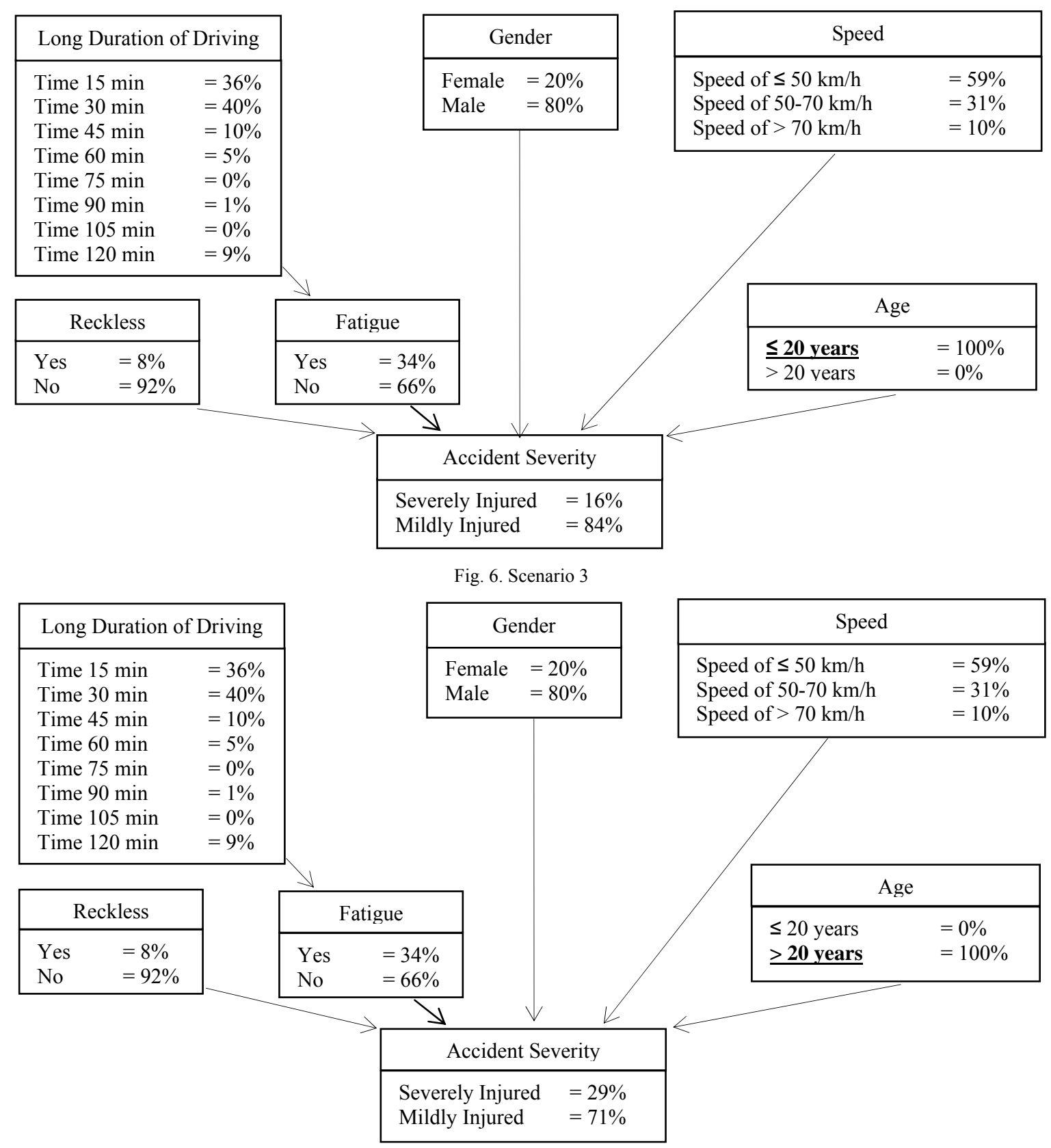

Fig. 7. Scenario 4 
Furthermore, motorcyclists who drive at a speed of $<50 \mathrm{~km} / \mathrm{h}$ and $50-70 \mathrm{~km} / \mathrm{h}$ are $20 \%$ more likely to suffer severely injuries in an accident, and to $23 \%$ at the speed $>70 \mathrm{~km} / \mathrm{h}$ as shown in Figure 8,9 and 10 (scenarios 5,6, and 7).

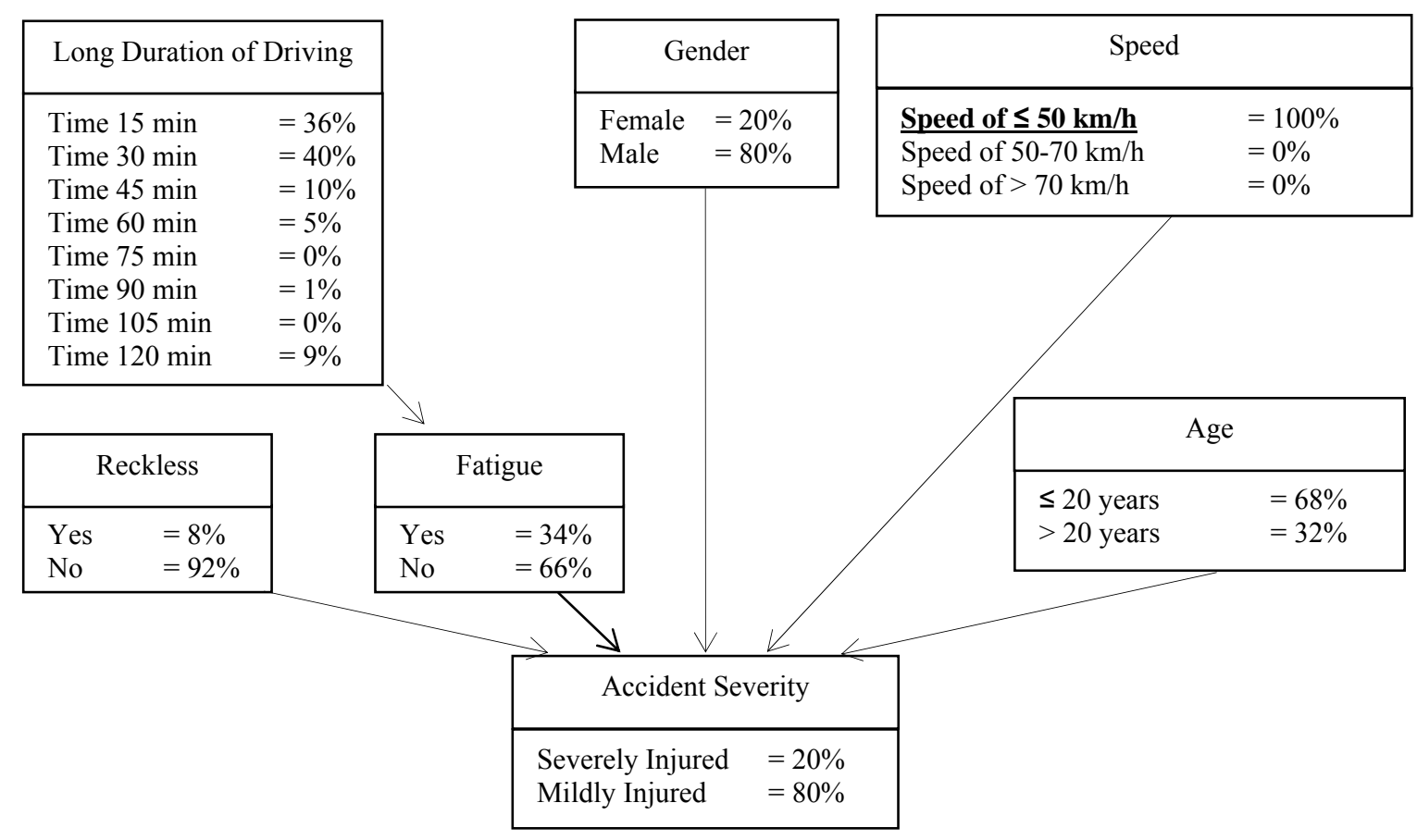

Fig. 8. Scenario 5

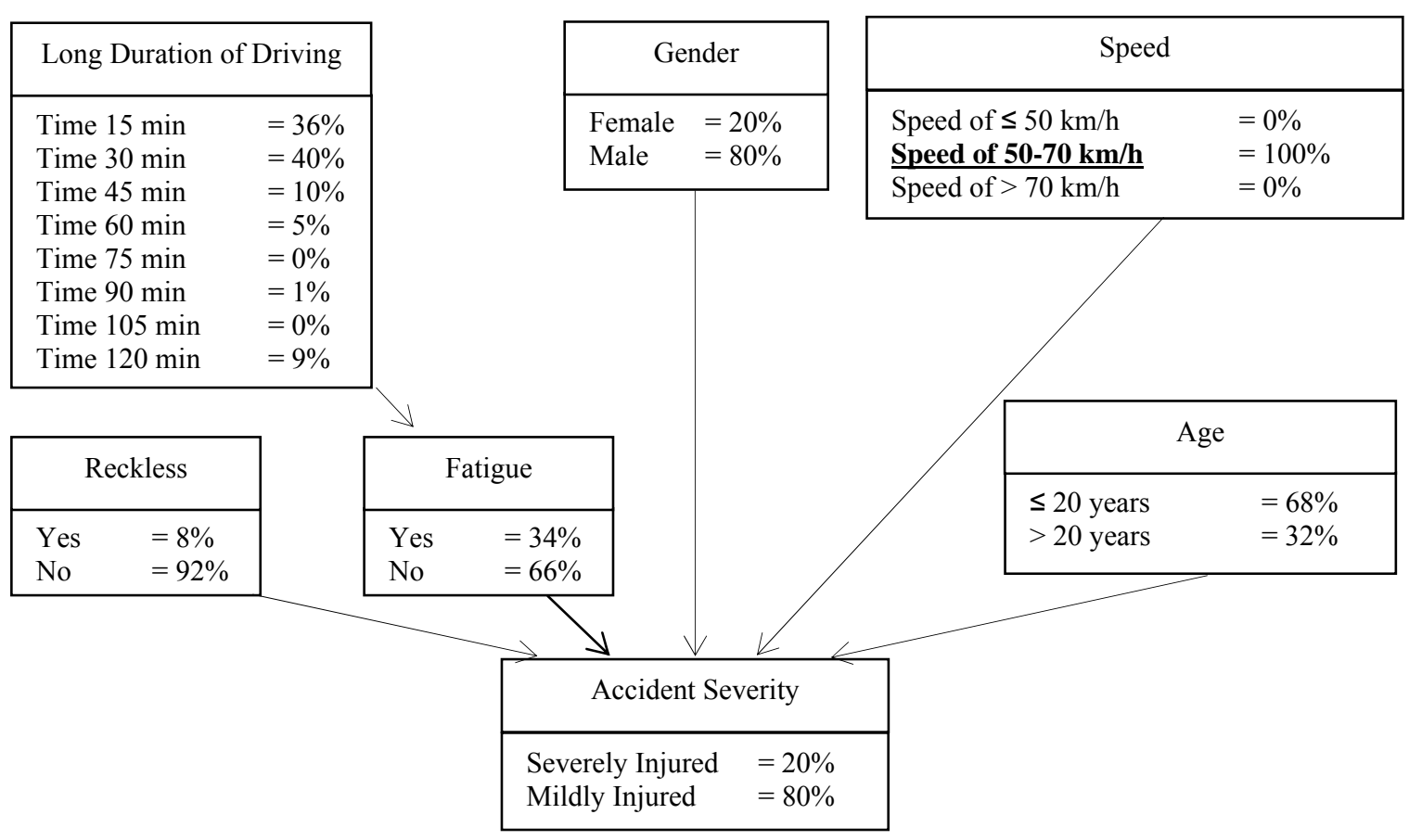

Fig. 9. Scenario 6 


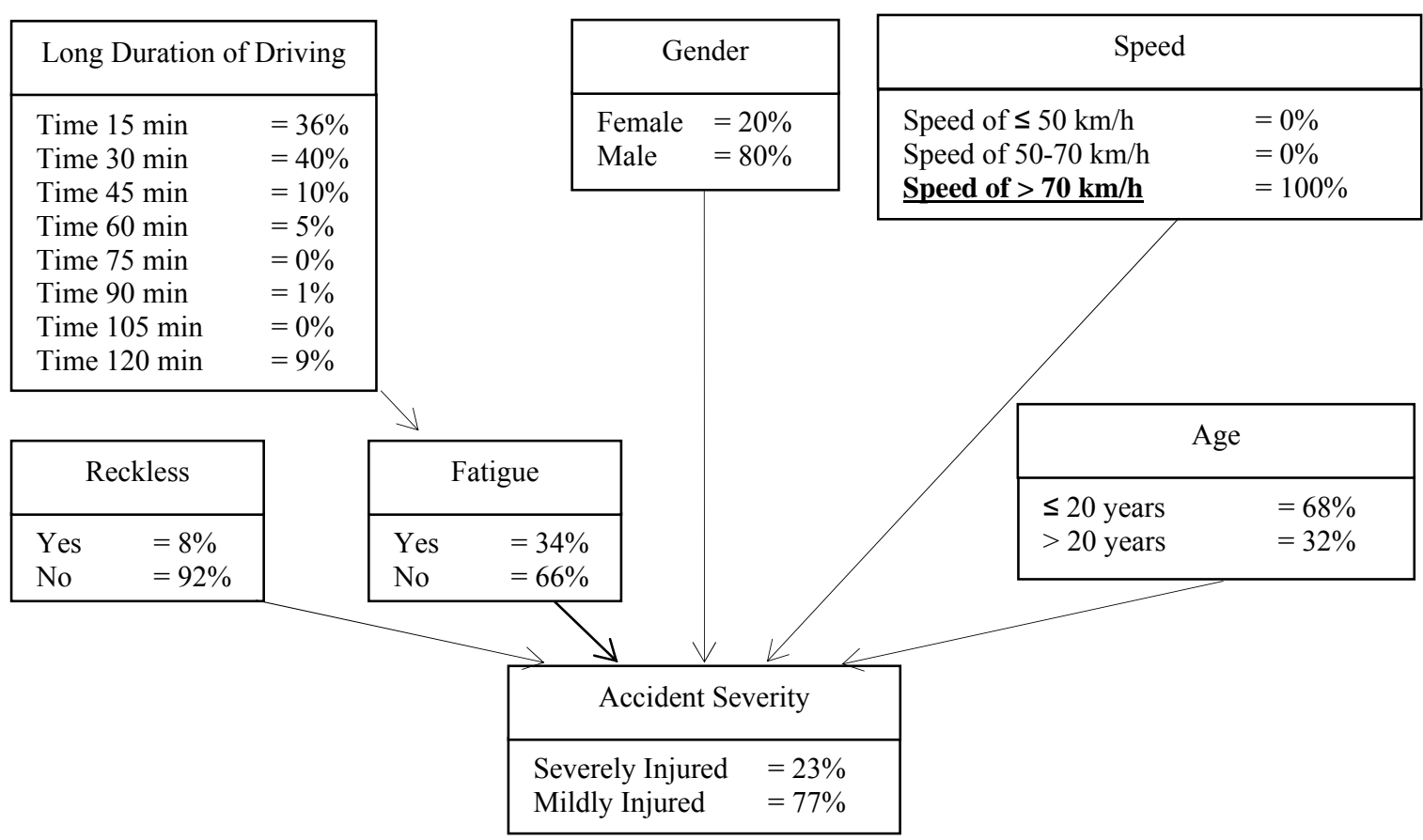

Fig. 10. Scenario 7

Reckless motorcyclists on the highway are $30 \%$ more likely to experience severely injuries in accidents as shown in Figure 11 and 12 (scenarios 8 and 9). This study is in accordance with the study conducted by [5] which states that speeding and recklessness are causes of fatal accidents for young drivers, and nearly $20 \%$ of fatal accidents are due to driving under the influence of alcohol and $4 \%$ under the influence of drugs. Speeding is the highest contributor to the severity of an accident [9]. In addition, high levels of aggressiveness increase the risk of severity of accidents for motorcyclists [9].

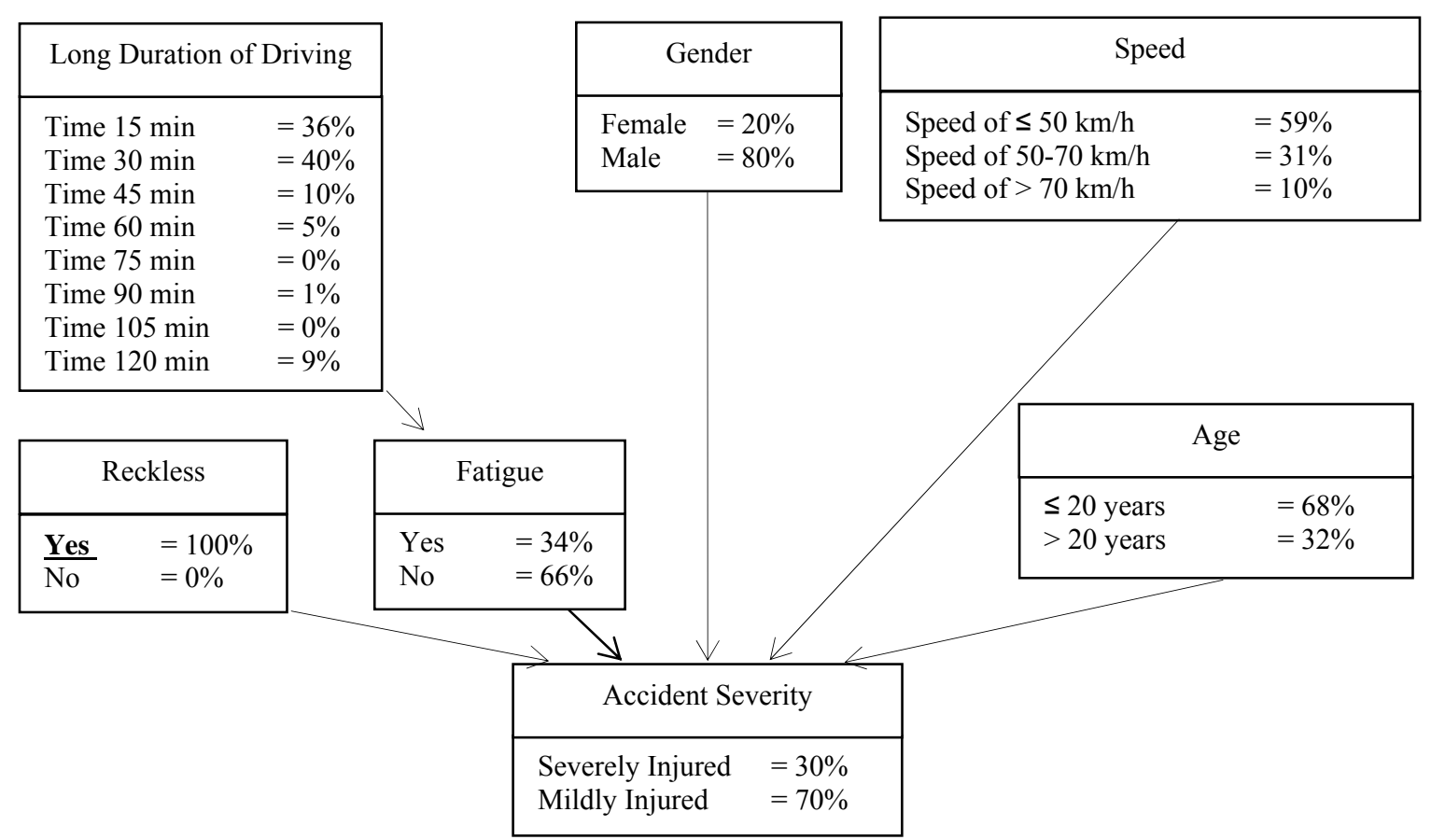

Fig. 11. Scenario 8 


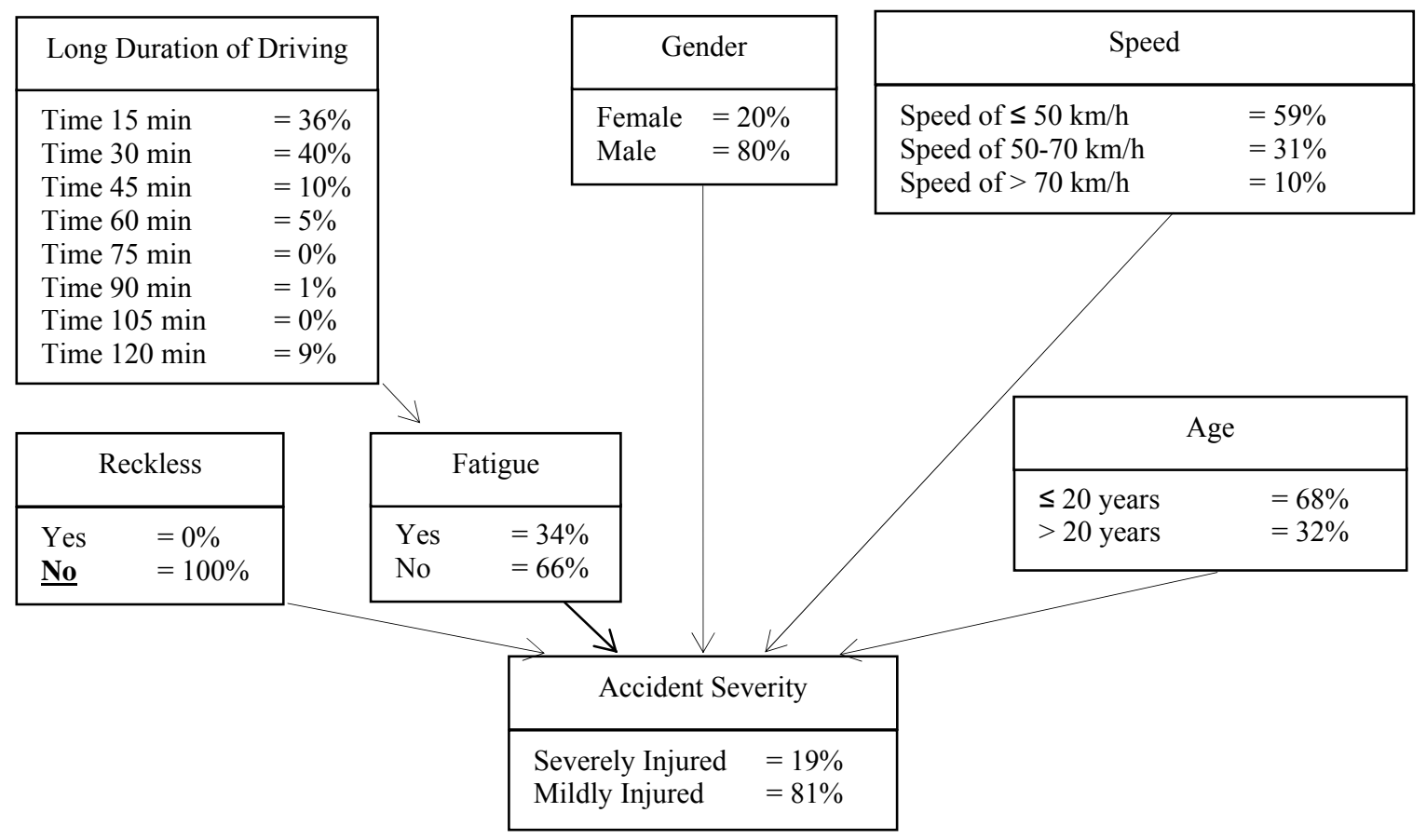

Fig. 12. Scenario 9

\section{CONCLUSION}

Based on the Bayesian Network analysis, there are several conclusions which can be drawn :

1. The structure of Bayesian Network in this study have several attributes that affect the probability of accidents and severity of severely injuries and mildly injuries including : long duration of driving, gender, age, speed, fatigue, and reckless behavior while driving.

2. The results of the Bayesian Network analysis indicate that the probability of an accident resulting in severely injuries was $20 \%$, while mildly injuries was $80 \%$.

3. Approximately $34.29 \%$ of accidents occurre due to fatigue, and bassicly long duration of driving is significantly cause of fatigue related accident.

4. Approximately $67.62 \%$ of accidents involving motorcyclists aged 20 years and under.

5. Speeding is more likely to increase the probability accident severity.

6. Analysis of Bayesian network indicate that 90 minute trip duration is the safe limit for higway driving in order to minimize the probability and severity of traffic accident.

\section{ACKNOWLEDGEMENT}

I would like express my sincere gratitude to The Ministry of Reseach, Technology and Higher Education, which provided scholarship for taking Doctoral Program at Universitas Gadjah Mada, Head of the Doctoral Program of Civil Engineering, Universitas Gadjah Mada, Supervisor who assisted in the preparation of this research article, and Co-Supervisor who assisted in the preparation of this research article.

\section{REFERENCES}

[1] Badan Pusat Statistik (BPS) Indonesia (2011)

[2] Badan Pusat Statistik (BPS) Indonesia (2012)

[3] Badan Pusat Statistik (BPS) Indonesia (2013)

[4] Badan Pusat Statistik (BPS) Indonesia (2014)

[5] Clarke, D.D ., Ward, P ., Bartle, C ., Truman, W, (2009), Older drivers' road traffic crashes in the UK, Accident Analysis and Prevention 42 (2010) 1018-1024, Elsevier

[6] Dissanayake, S ., Perera, L, (2011), “A Survey Based Study of Factors Related to Older driver Highway Safety” Journal of Transportation Safety \& Security

[7] Dingus, T. A., Neale, V. L., Klauer, S. G., Petersen, A. D. and Carroll, R. J. (2006) The development of a naturalistic data collection system to perform critical Incident analysis: an investigation of safety and fatigue issues in long-haul trucking. Accident Analysis and Prevention, 38(6), 1127-1136.

[8] Dotzauer, M ., Waard, D.D ., Caljouw, S.R ., Pöhler, G ., Brouwer, W.H, (2014), Behavioral adaptation of young and older drivers to an intersection crossing advisory system, Accident Analysis and Prevention 74 (2014) 24-32, Elsevier

[9] Eliana, D (2015), Pengaruh agresivitas dan kecepatan terhadap tingkat keparahan cedera akibat kecelakaan lalulintas pada pengemudi sepeda motor di Kabupaten Bantul, Tesis, Ilmu Kesehatan Masyarakat, Universitas Gadjah Mada

[10] Eustace, D ., Wei, H, (2010)“The Role of Driver Age and Gender in Motor Vehicle Fatal Crashes” Journal of Transportation Safety \& Security 
[11] Hensher, D A, DANIELS, R, Battellino, H, 1992, Safety and productivity in the long distance trucking industry, proceeding, $16^{\text {th }}$ ARRB Conference, 9-13 November 1992, Perth, Western Australia, Volume 16, Part 4

[12] https://dslpitt.org/genie/wiki/GeNIe Documentation

[13] Korlantas Polri, (2015)

[14] Lapparent, M.D. (2005), "Individual cyclists' probability distributions of severe/fatal crashes in large french urban areas", Accident Analysis and Prevention 37 (2005) 1086-1092

[15] Ma, T., Wiliamson, A. and Friswell, R. (2003) A Pilot Study of Fatigue on Motorcycle Day Trips. Sydney, Australia: NSW Injury Risk Management Research Centre.

[16] Mannering, F.L dan Grodsky, LL, (1994), Statistical Analysis of Motorcyclists’ Perceived Accident Risk, OoOl-4575(94)00041-7, Pergamon

[17] Oluwadiyaa, K.S ., Kolawoleb, I.K ., Adegbehingbed, O.O ., Olasindee, A.A ., Agodirina, O, Uwaezuokec, S.C, (2008) "Motorcycle crash characteristics in Nigeria: Implication for control" Accident Analysis and Prevention 41 (2009) 294-298

[18] Pearl, J ., dan Russel, S, (2001), "Bayesian networks", Handbook of brain theory and neural

[19] Sexton, B., Baughan, C., Elliott, M. and Maycock, G. (2004) The Accident Risk of Motorcyclists.TRL Report No. 607. Crowthorne: TRL Limited.

[20] Susilo, Y. O ., Joewono, T.B ., Vandebona, U, (2014), Reasons underlying behaviour of motorcyclists disregarding traffic regulations in urban areas of Indonesia, Accident Analysis and Prevention 75 (2015) 272-284

[21] Ting, P.H ., Hwang, J.R ., Doong, J.L ., Jeng, M.C, (2007), Driver fatigue and highway driving: A simulator study, Physiology \& Behavior 94 (2008) 448-453, Elsevier

[22] Vorko-Jovic,A ., Kern,J., Biloglav, Z, (2005), Risk factors in urban road traffic accidents, Journal of Safety Research 37 (2006) 93 - 98, Pergamon

[23] Wong, J.T ., Chung, Y.S ., Huang, S.H. (2009), "Determinants behind young motorcyclists' risky riding behavior", Accident Analysis and Prevention 42 (2010) 275-281

[24] Zhou, H ., Zhao, J ., Gahrooei, M.R ., Priscilla A. (2016), "Identification of contributing factors for wrong-way crashes on freeways in Illinois", Journal of Transportation Safety \& Security

\section{AUTHOR PROFILE}

Pada Lumba is a doctoral student in Gadjah Mada University, Indonesia. He has obtained his Master degree in Magister of Transportation System and Engineering from Gadjah Mada University in 2006. His areas research interests is road traffic safety.

Imam Muthohar is a lecturer in Gadjah Mada University, Indonesia. He earned a M.Sc in Magister of Transportation System and Engineering from Gadjah Mada University in 2004. He earned his Ph.D. in Kyushu University in Japan in 2011. His areas research interest include transport planning and policy.

Sigit Priyanto is a Professor in Gadjah Mada University, Indonesia. He earned his Master degree in Delft University of Technology in 1989. He earned his Ph.D in The University of Leeds in 1994. His areas research interests include: traffic safety, transport planning and modelling, traffic flow theory. 